\title{
電気瘆攣療法(ECT) を受ける難台性慢性疼痛患者の原大疾患別に夕大心理的特徵
}

○小林如乃

(早稻田大学大学院人間科学研究科)
土井永史

米良仁志

野村忍

（東京大学医学部付属病院精神神経科）（東京都保健医療公社荏原病院麻酔科）（早稲田大学人間科学学術院） key words : 慢性疼痛, 心理検査, 電気痤攣療法 (ECT)

【はじめに】電気瘥攣療法 (electroconvulsive therapy : 以下 ECT 治療）は統合失調症やうつ病に対寸る治療法として 確立されているが，本邦では難治性慢性疼痛に対しても適応 となっており, ECT 治療が実施されている。難治性慢性疼痛 患者は，身体的な感覚としての苦痛と同時に持続的に不快な 情動体験を強いられていることから，不安定な心理的状態に あることが多い。また, 疼痛によって通常の日常生活における 行動様式の変容を迫られることや周囲からの理解を得にくい こと，罹病期間ならびに治療期間が長期にわたる場合が多い ことなどから，患者は恒常的に強度の心理的負担を強いられ ていると考えられる。なかでも ECT の対象となる患者は，極 端に疼痛症状の程度が高く，心理的負荷も高いことが考えら れる。原因疾患の違いによって心理的負担に特徴があれば早 期より効果的な心理面へのアプローチの可能性が考えられる。 【目的】本研究は, ECT 治療を受ける難治性慢性疼痛患者の原 因疾患の違いによる心理的特徵を検討することを目的とする。

【方法】1）対象者：総合病院精神科・麻酔科にて ECT 治療 を受けた患者のうち，最終有効回答を得ることのできた 63 名 (男性 48 名, 女性 15 名) に対して, 面接および質問紙調查 を行った。平均年齢は 55.00 歳 $(\mathrm{SD}=15.69)$, 男性の平均年齢 は54.44歳 $(\mathrm{SD}=15.71)$, 女性の平均年齢は 56.80 歳 $(\mathrm{SD}=16.01)$ であった。対象となった患者の原因疾患は, 視床痛, 外傷後 CRPS ならびに手術後 CRPS, 帯状疮疹後神経痛, 線維筋痛症で あった。2）調查方法：ECT 患者に対して, 調査への協力 の是非を確認した後，同意を得ることのできた患者にのみ調 查を行った。3）倫理的配慮：調查について十分な説明を 行い，調査の趣旨を理解したうえで同意を得られた患者に対 してのみ, 面接調查及び質問紙調查を行った。また, 調查を 拒否したり途中でやめたりしても何等の不利益も被らないこ と，治療の妨げにはならないことを説明した。なお，調査に あたってはプライバシーを確保した。4）調査内容：(1) 対象者の属性 : 年齢, 性別, 職業の有無，家族構成および同 居家族の有無，原因疾患，罹病期間などを尋祘た。(2) 使用 した測度 : 面接調查においては HDRS (Hamilton Depression Rating Scale), 質問紙調查においては日本版 GHQ60, CMI 健 康調查表, CRS（日本語版キャロル抑うつ自己評価尺度）, 達 成動機測定尺度，ゆとり(感)尺度を使用し，一部の患者には さらに YG 性格検查, STAI 不安尺度を使用した。また, 痛み の程度はVASによって評価した。

【結果】原因疾患により, 視床痛群, CRPS 群, 帯状疮疹後 神経痛群，線維筋痛症群に分類した。原因疾患群を独立変数 とし, HDRS を除く各心理検查の得点を従属変数とする一元配 置の分散分析を行い，有意傾向がみられたものに対して Tukey 法による多重比較を行った。HDRS では $31.7 \%$ 軽度, 46. $0 \%$ が中等度, $7.9 \%$ が重度に分類された。原因疾患別では, 視床痛群は $50.0 \%$ が軽度, $36.4 \%$ が中等度に分類され，帯状疮 疹後神経痛群は $25.0 \%$ が軽度， $50.0 \%$ が中等度に分類され， CRPS 群は $19.4 \%$ が軽度, $51.6 \%$ が中等度, $16.1 \%$ が重度に分類 され，線維筋痛症群は $33.3 \%$ が軽度，50.0\%が中等度に分類さ れたが，群間による有意差はみられなかった。GHQでは，す べての原因疾患群の総合得点ならびに 4 下位尺度のすべてに おいて, 健常者サンプルの平均得点よりも高得点を示したが,
原因疾患群の群間に有意差はみられなかった。また, 総合得 点の判別では, すべての原因疾患群において臨床場面での区 分点(12/13) よりも高得点を示した。CMI では, 身体的自覚症 得点ならびに精神的自覚症得点ともに大学生サンプルの平均 得点よりも高得点を示したが，原因疾患群の群間に有意差は みられなかった。領域の結果は $14.3 \%$ I I 領域, $22.2 \%$ II 領域, $42.9 \%$ が III 領域, $20.6 \%$ が IV 領域に分類された。原 因疾患別では, 視床痛群は $18.2 \%$ が I 領域, $22.7 \%$ が II 領域, $40.9 \%$ が III 領域, $18.2 \%$ が IV 領域に分類され, 帯状疮疹後 神経痛群は $25.0 \%$ が I 領域, $50.0 \%$ が II 領域, $25.0 \%$ が IV 領 域に分類され，CRPS 群は $12.9 \%$ I 領域，19.4\%が II 領域， $45.2 \%$ が III 領域, $22.6 \%$ が IV 領域に分類され, 線維筋痛症 群は 14.3\%が II 領域, $71.4 \%$ が III 領域, $14.3 \%$ が IV 領域 に分類されたが，群間による有意差はみられなかった。CRS では, すべての原因疾患群において正常サンプルの平均得点 よりも高得点を示したが，原因疾患群の群間に有意差はみら れなかった。また, すべての原因疾患群において区分点 (16/17) よりも高得点を示した。達成動機測定尺度では, 2 下 位尺度のうち自己充実的達成動機尺度に関しては視床痛群, CRPS 群, 帯状疱疹後神経痛群において大学生サンプルの平均 点よりも低得点を示し, 競争的達成動機尺度に関してはすべ ての原因疾患群において大学生サンプルの平均点よりも低得 点を示した。自己充実的達成動機において有意差がみられ $(F(3,59)=3.25, p<.05)$, 競争的達成動機尺度得点において有 意差がみられた $(F(3,59)=7.16, p<.001)$ ため多重比較を行っ たところ, 帯状疮疹後神経痛群では, 自己充実的達成動機尺 度得点において線維筋痛症群よりも有意に低く $(p<.05)$, 帯状 疮疹後神経痛群の得点が他の 3 群よりも有意に低かった（視 床痛群: $p<.001$, CRPS 群: $p<.01$, その他の原因疾患群: $p<.01)$ 。 ゆとり(感) 尺度では, 8 下位尺度のうち遊楽性尺度, 挑戦性 尺度, 満足安定性尺度, 自由奔放性尺度において一般サンプ ルの平均点よりも低得点であった。満足安定性尺度得点にお いて有意差がみられた $(F(3,59)=3.60, p<.01)$ ため多重比 較を行ったところ, 線維筋痛症群の得点が帯状疮疹後神経痛 群よりも有意に低かった $(p<.05)$ 。また, YG 性格検查と STAI 不安尺度の結果については, 視床痛群, CRPS 群, 線維筋痛症 群の 3 群において, 原因疾患群を独立変数とし, 各結果の 5 段階標準得点を従属変数としてKruskal Wallis 検定を行った ところ，YG 性格検查では，12 下位尺度のうち R(rathymia) 尺 度と S(social extraversion) 尺度において有意差がみられた (R: $p<.05, \mathrm{~S}: p<.05)$ 。また, STAI では, 状態不安尺度につい て高不安 (4 段階・5 段階)が 85.7\%であったのに対して, 特性 不安尺度について高不安 (4 段階) は 14.3\%であり, 群間に有意 差はみられなかった。

【考察】ECT 患者では抑うつの程度や神経症の重症度分類等 において, 一部の結果を除いて原因疾患による差は少ないも のの, 全般的に心的負担の大きい状態であることが示された。 また, 有意差はないものの繊維筋痛症群において, 他の群に 比べて心的負担が大きい得点結果が示されたことから, 線維 筋痛症について更なる検討を行うことが今後の課題である。

(YUKINO Kobayashi, NAGAFUMI Doi, HITOSHI Mera, SHINOBU Nomura) 